\title{
Influence of Potassium Addition on Productivity, Quality and Nutrient Uptake of Mungbean (Vigna
}

\section{radiata $\mathrm{L}$.}

\author{
Md.Abdul Quddus
}

Soil and Water Management Section, Horticulture Research Centre, Bangladesh Agricultural Research Institute, Gazipur, Bangladesh. E-mail: Quddus06@yahoo.com

Md.Ashraf Hossain, Habib Mahammad Naser

Soil Science Division, Bangladesh Agricultural Research Institute, Gazipur, Bangladesh.

E-mail: ashrafbd61@yahoo.com,nasemh2@yahoo.com

Babul Anwar

Regional Agricultural Research Station, Bangladesh Agricultural Research Institute, Jashore, Bangladesh. E-mail: babul.bari08@yahoo.com

\section{Md. Alamgir Siddiky}

Soil and Water Management Section, Horticulture Research Centre, Bangladesh Agricultural Research Institute, Gazipur, Bangladesh. E-mail: siddiky71@bari.gov.bd

Md. Razzab Ali

Olericulture Division, Horticulture Research Centre, Bangladesh Agricultural Research Institute, Gazipur, Bangladesh. E-mail: razzab321@gmail.com

Received: Nov. 4, 2018

doi:10.5296/jas.v7i1.14269
Accepted: Jan. 6, 2019

Published: Jan. 26, 2019

URL: https://doi.org/10.5296/jas.v7i1.14269

\begin{abstract}
Potassium is the key element for mungbean (Vigna radiata L.) productivity. The study was carried out to understand the effects of potassium $(\mathrm{K})$ on mungbean productivity, quality, nutrient content and nutrient uptake and how this element can help to manage soil fertility.Therefore, an experiment was conducted during two consecutive years 2016 and 2017. The experiment was laid out in randomized complete block design considering six treatments with thrice replicates. The treatments were $\mathrm{T}_{1}=$ Control, $\mathrm{T}_{2}=30 \mathrm{~kg} \mathrm{~K} \mathrm{ha}{ }^{-1}, \mathrm{~T}_{3}=40$ $\mathrm{kg} \mathrm{K} \mathrm{ha}{ }^{-1}, \mathrm{~T}_{4}=50 \mathrm{~kg} \mathrm{~K} \mathrm{ha}^{-1}, \mathrm{~T}_{5}=60 \mathrm{~kg} \mathrm{~K} \mathrm{ha}^{-1}$ and $\mathrm{T}_{6}=70 \mathrm{~kg} \mathrm{~K} \mathrm{ha}^{-1}$ along with the blanket dose of $\mathrm{N}_{15} \mathrm{P}_{20} \mathrm{~S}_{10} \mathrm{Zn}_{2} \mathrm{~B}_{1.5} \mathrm{~kg} \mathrm{ha}{ }^{-1}$. Results revealed that application of different levels of
\end{abstract}


potassium showed significant effects on the plant height, number of pods per plant, number of seeds per pod and thousand seed weight which were influenced to obtain higher yield of mungbean. The highest average seed yield $\left(1476 \mathrm{~kg} \mathrm{ha}^{-1}\right)$ and highest yield increment $(39.5 \%)$ of mungbean were produced from the treatment $\mathrm{T}_{5}$. Most of the cases the highest nutrient $(\mathrm{N}$, $\mathrm{P}, \mathrm{K}, \mathrm{S}, \mathrm{Zn}$ and $\mathrm{B}$ ) content was obtained in $\mathrm{T}_{5}$ treatment.The highest $\mathrm{K}$ uptake by mungbean, maximum nodulation, the highest protein content in seed and maximum apparent $\mathrm{K}$ recovery efficiency $(54.8 \%)$ were, however, recorded from the treatment receiving of $60 \mathrm{~kg} \mathrm{~K} \mathrm{ha}^{-1}$. It was concluded that proper use of $\mathrm{K}$ with other nutrients facilitated to improve the productivity and quality of mungbean and also $\mathrm{K}$ played a significant role in maintaining soil fertility.

Keywords: potassium, mungbean yield, nutrient content, potassium uptake and balance, soil properties

\section{Introduction}

Mungbean (Vigna radiata L.) is an important summer pulse crop in Asia under Fabaceae family and known as green gram. It is a short durative (60 to 90 days) crop during spring and autumn seasons (Hussain et al., 2016; Sadaf and Tahir, 2017). It has high nutritive value which contains $24.2 \%$ protein, $1.3 \%$ fat and $60.4 \%$ carbohydrate. The mungbean sprout is rich in vitamins and amino acids (Hussain et al., 2011; Saket Kumar et al., 2018). Mungbean enhances the soil fertility through biologically nitrogen fixation from 63 to $342 \mathrm{~kg} \mathrm{ha}^{-1}$ (Sadaf and Tahir, 2017; Kaisher et al., 2010). The average yield of mungbean in Bangladesh is about $867 \mathrm{~kg} \mathrm{ha}^{-1}$ i.e. low (BBS, 2016); however attention should be taken up by the crop experts. It is evident from the literature that judicial application of macro and micro nutrients, especially $\mathrm{K}$ enhances the yield of mungbean (Ali et al., 2010). Owing to the high mobility of $\mathrm{K}$ in plants and its considerably high accumulation in the cytoplasm as compared with other essential cations, its deficiency is frequently encountered in most soils (Mengel and Kirkby, 1987). Plants require the largest amounts of potassium for photosynthesis, protein synthesis and resilience against abiotic stresses (Arif et al., 2008; Grag et al., 2005). Potassium improves plant water relationship and improves mungbean shoot growth (Kabir et al., 2004). It maintains turgor pressure of cell which is necessary for cell expansion. It helps in osmo-regulation of plant cell, assists in opening and closing of stomata (Yang et al., 2004). Potassium nutrition is associated with the nodulation; grain quality and protein content (Srinivasarao et al., 2003). It also helps to improve disease resistance, drought stress, tolerance to water stress, winter hardiness, tolerance to plant pests and uptake efficiency of other nutrients (Gupta et al., 2013). However, it is well-known that the availability of $\mathrm{K}$ to plants does not only depend on the size of the available pool in the soil, but also on the transport of $\mathrm{K}$ from soil solution to the root zone and from the root zone into plant roots (Barber, 1995). Quddus (2014) observed that pulses crops need a sizable amount of K for good vegetative growth and influenced reproductive phase due to higher uptake from soil. Due to high demand of food for rapid growing population, cropping intensity had been increased with high yielding varieties of crops followed non judicial fertilizer use and poor management practices, however resulted a considerable amount of potassium depleted (Ahmad Alias et al., 2012). 
The above circumstances, the $\mathrm{K}$ management become very important in sustaining or increasing mungbean quality and productivity. Therefore, the present study was undertaken to estimate the suitable doses of $\mathrm{K}$ for nodulation, quality and yield maximization of mungbean as well as to measure the nutrient use efficiency.

\section{Materials and Methods}

\subsection{Site Description and Soil}

The field experiment was conducted for two consecutive years of 2016 and 2017 at the research field of Regional Agricultural Research Station (RARS), Bangladesh Agricultural Research Institute (BARI) located in Jashore $\left(23.11^{\circ} \mathrm{N}\right.$ latitude and $89.14^{\circ} \mathrm{E}$ longitude) lies at an elevation of $6.71 \mathrm{~m}$ above the sea level. The land belongs to Gopalpur soil series (Soil taxonomy: order-Inceptisols and sub-group-Aquic Eutrochrepts) under High Ganges River Floodplain agroecological zone-11. The soils of Jashore are calcareous in nature having silt loam texture (\% sand $16.43, \%$ silt 63.21 and \% clay 20.36). Initially the soil properties such as the soil $\mathrm{pH}$ value was 8.2 , organic matter $1.61 \%$, total $\mathrm{N} 0.073 \%$, exchangeable $\mathrm{K} 0.12$ meq. $100 \mathrm{~g}^{-1}$, exchangeable Ca 18.0 meq. $100 \mathrm{~g}^{-1}$, exchangeable $\mathrm{Mg} 1.75$ meq. $100 \mathrm{~g}^{-1}$, available P $14.6 \mu \mathrm{g} \mathrm{g}^{-1}$, available S $15.5 \mu \mathrm{g} \mathrm{g}^{-1}$, available $\mathrm{Zn} 0.80 \mu \mathrm{g} \mathrm{g}^{-1}$ and available B 0.16 $\mu \mathrm{g} \mathrm{g}^{-1}$ (Table 6).

The experimental site has subtropical humid climate characterized by comparatively heavy rainfall, high humidity, high temperature, long days with less clear sunshine during April to September. Scanty rainfall, low humidity, low temperature, short days and more clear sunshine characterized during October to March. The average temperature ranges from 20 to $35^{\circ} \mathrm{C}$ and average annual rainfall varies from 1650 to $2000 \mathrm{~mm}$ across the year. The meteorological data of the experimental period like average rainfall received from 1.7 to 165 $\mathrm{mm}$ during January to June 2016 and 0.0 to $156 \mathrm{~mm}$ during January to June 2017. The mean minimum and maximum air temperatures during January to June of the experiment were 9.46 and $37.9{ }^{\circ} \mathrm{C}$, respectively. The average minimum and maximum humidity (\%) were 71.4 and 88.8 during January to June (Table 1).

Table 1. Weather data during the experimental period at Jashore

\begin{tabular}{lccccccccccc}
\hline \multirow{4}{*}{ Months } & \multicolumn{3}{c}{ Avg. Temperature $\left({ }^{\circ} \mathrm{C}\right)$} & \multicolumn{3}{c}{ Avg. Humidity (\%) } & \multicolumn{3}{c}{ Rainfall (mm) } \\
& \multicolumn{2}{c}{ 2016 } & \multicolumn{2}{c}{ 2017 } & \multicolumn{2}{c}{ 2016 } & 2017 & 2016 & 2017 \\
& Min. Max. Min. Max. Min. Max. Min. Max. & - & - \\
\hline January & 10.3 & 23.9 & 9.46 & 26.7 & 73.3 & 83.4 & 71.4 & 80.1 & 1.7 & 0.0 \\
February & 15.7 & 27.1 & 10.7 & 27.8 & 77.4 & 83.5 & 73.7 & 79.9 & 15 & 0.0 \\
March & 18.6 & 30.4 & 14.7 & 32.5 & 76.3 & 84.4 & 73.8 & 80.0 & 20 & 7.9 \\
April & 24.6 & 37.9 & 16.5 & 33.5 & 76.4 & 83.2 & 74.8 & 82.0 & 45 & 107 \\
May & 23.5 & 36.6 & 21.4 & 36.2 & 76.0 & 88.3 & 74.6 & 84.8 & 165 & 148 \\
June & 25.9 & 31.4 & 20.1 & 34.5 & 80.2 & 88.8 & 76.9 & 85.3 & 149 & 156 \\
\hline
\end{tabular}

Source: Weather centre, RARS, Jashore, Bangladesh

\subsection{Land Preparation, Layout and Fertilizer Application}

The land was first opened by a tractor (TAFE $35 \mathrm{DI}$ ) and prepared thoroughly by ploughing with a power tiller (12 HP two wheel Sifang) followed by laddering and leveling. The clods 
were broken and the fields were made weed and stubbles free. The experiment was laid out in a randomized complete block design (RCBD) consisted of six treatments and thrice replicates. The unit plot size was $4 \mathrm{~m} \times 3 \mathrm{~m}$. The unit plots were separated from each other by an alley of $50 \mathrm{~cm}$ width. Thrice replicated blocks were alienated by the space of $75 \mathrm{~cm}$ width. The 6 (six) treatments were $\mathrm{T}_{1}=$ Control, $\mathrm{T}_{2}=30 \mathrm{~kg} \mathrm{~K} \mathrm{ha}^{-1}, \mathrm{~T}_{3}=40 \mathrm{~kg} \mathrm{~K} \mathrm{ha}^{-1}, \mathrm{~T}_{4}=50 \mathrm{~kg} \mathrm{~K} \mathrm{ha}^{-1}, \mathrm{~T}_{5}=$ $60 \mathrm{~kg} \mathrm{~K} \mathrm{ha}^{-1}$ and $\mathrm{T}_{6}=70 \mathrm{~kg} \mathrm{~K} \mathrm{ha}^{-1}$ along with the blanket dose of $\mathrm{N}_{15} \mathrm{P}_{20} \mathrm{~S}_{10} \mathrm{Zn}_{2} \mathrm{~B}_{1.5} \mathrm{~kg} \mathrm{ha}^{-1}$. All fertilizers were applied as basal in the whole respective treatment plot. The sources of $\mathrm{N}$, $\mathrm{P}, \mathrm{K}, \mathrm{S}, \mathrm{Zn}$ and B were urea, triple super phosphate (TSP), muriate of potash (MoP), gypsum, zinc sulphate and boric acid, respectively.

\subsection{Seed Sowing and Agronomic Practices}

A high yielding variety of mungbean (BARI Mung-6) seeds were treated by the fungicide of Provex 200 (at $2.5 \mathrm{~g} \mathrm{~kg}^{-1}$ seeds) before sowing for controlling of soil born diseases. Treated seeds were sown at $30 \mathrm{~kg} \mathrm{ha}^{-1}$ on 11 March 2016 and 13 March 2017. Each plot size was 12 $\mathrm{m}^{2}(4 \mathrm{~m} \times 3 \mathrm{~m})$ and seeds were sown continued in rows (10 rows) maintained the space between row to row of $30 \mathrm{~cm}$. Hand weeding as well as thinnng of seedlings were done at 15 days after sowing (DAS), maintaining the distance of plant to plant $10 \mathrm{~cm}$ by making a total of 400 plants per plot $\left(12 \mathrm{~m}^{2}\right.$ ). The insects (pod borer and thrips) were controlled by spraying insecticide of Karate (Syngenta) at $2 \mathrm{ml} \mathrm{L}^{-1}$ during three times at flowering and podding stage interval of 10 days. Irrigation was applied when required. First harvest was started from $2^{\text {nd }}$ week of May in both the years. The harvested pods of mungbean were brought to the threshing floor for sun drying. The seeds were separated with the help of bamboo stick.

\subsection{Data Collection, Soil and Plant Analysis}

Nodulation counting was made on flowering stage. Five plants were smoothly uprooted and carefully removed the soil from roots using tap water. Then washed the roots with distilled water, blotted with tissue paper and counted the number of nodules. Nodules were separated from the roots and cut into two pieces and observed the inside color for nodules activity. The nodules those were light-pink or red coloured considered as active. Regarding yields attributes viz. plant height, number of branch per plant, pod length, number of pods per plant and seeds per pod: - mature 10 plants of mungbean were randomly selected and tagged in each treatment plot at $1^{\text {st }}$ harvest. Plant height and number of branches per plant were recorded from above ground part and averaged. Mature pods were detached from every plant and count the data of number of pods per plant and averaged. Ten pods were separated randomly from composite pods of ten plant of each plot. Pod length was measured and number of seeds per pod were counted from each pod of separated ten pods and averaged. Then treatment wise seeds of 10 plants were preserved in Poly bag $(10 \mathrm{~cm} \times 15 \mathrm{~cm})$. For stover and seed yields $\left(\mathrm{kg} \mathrm{ha}^{-1}\right)$ were measured based on whole plot $(4 \mathrm{~m} \times 3 \mathrm{~m})$ technique. Plot wise grand total seeds (seeds of ten plant+seeds of area of whole plot) were sun dried and adjusted to moisture content around $10 \%$ based on the value of actual moisture measured by digital seed moisture tester manual (Seedburo 1200D Digital Moisture Tester Manual, USA).Thousand seed weight (g) was determined by the counting of 500 seeds randomly from composite seeds of each plot and weighing through electronic balance and converting it into 
1000 -seed weight after adjusting around $10 \%$ moisture content.

Treatment-wise soil samples at $0-15 \mathrm{~cm}$ were collected after crop harvest. The composite soil sample of each plot was brought to the laboratory and spread on a brown paper for air drying. The air-dried soil samples were ground and passed through a 2-mm sieve. After sieving, the prepared soil samples were kept into plastic containers with proper label for analysis. Particle size analysis of the initial soil was conducted using the hydrometer method (Black, 1965). The textural class was determined using Marshall's Triangular Coordinates of the USDA system. The initial and final soil samples were analyzed for soil $\mathrm{pH}$ were measured by glass electrode $\mathrm{pH}$ meter using soil: water ratio of 1:2.5 (Page et al., 1982) and organic matter by Nelson and Sommers (1982) method; total N by Microkjeldahl method (Bremner and Mulvaney, 1982); exchangeable $\mathrm{K}$ by $1 \mathrm{~N} \mathrm{NH}_{4} \mathrm{OAc}$ method (Jackson,1973); exchangeable Ca and $\mathrm{Mg}$ by $1 \mathrm{~N} \mathrm{NH}_{4} \mathrm{OAc}$ method (Gupta, 2004); available P by Olsen and Sommers (1982) method; available $\mathrm{S}$ by turbidity method using $\mathrm{BaCl}_{2}$ (Fox et al., 1964); available $\mathrm{Zn}$ by DTPA method (Lindsay and Norvell, 1978); available B by azomethine-H method (Page et al., 1982).

Plant samples (stover and seed) to each treatment plot were oven-dried at $70^{\circ} \mathrm{C}$ for $48 \mathrm{~h}$ and finely ground by a Cyclotec ${ }^{\mathrm{TM}} 1093$ sample Mill (Made in Sweden). Treatment wise ground samples (100 g of stover and $100 \mathrm{~g}$ of seeds) were stored in poly bag (size, $15 \mathrm{~cm} \mathrm{x} 10 \mathrm{~cm}$ ) for analysis. Afterwards, $0.1 \mathrm{~g}$ of each of the ground samples (stover and seeds) was analysed for $\mathrm{N}$ using the Kjeldahl method FOSS (Persson et al., 2008). Oven-dried each ground sample of $0.5 \mathrm{~g}$ was taken in a $50 \mathrm{ml}$ digestion flask; $5 \mathrm{ml}$ of diacid mixture $\left(\mathrm{HNO}_{3}\right.$ and $\left.\mathrm{HClO}_{4}\right)$ as described by Piper (1966) was added to the flask. The flask was placed on hot plate and the temperature was raised upto $190^{\circ} \mathrm{C}$ and the digestion was done for 2 hours. The flask was then removed and allowed to cool upto room temperature. The samples were diluted with distilled water and filtered through a filter paper (Whatman No. 42) in a $100 \mathrm{ml}$ volumetric flask and volume was made up to the mark by adding distilled water. Determined the content of $\mathrm{P}$ (spectrophotometer method), $\mathrm{K}$ (atomic absorption spectrophotometer method), $\mathrm{S}$ (turbidity method using $\mathrm{BaCl}_{2}$ by spectrophotometer as Chapman and Pratt (1964), for $\mathrm{Zn}$ concentration in the digestion was directly measured by Atomic Absorption Spectrophotometer (VARIAN SpectrAA 55B, Australia). Boron concentration was determined by spectrophotometer following azomethine-H method (Page et al., 1982).

Protein content in mungbean seed was estimated on considering the nitrogen percentage.The protein content was estimated by multiplying the $\% \mathrm{~N}$ content of seed with constant factor 6.25 that means $\% \mathrm{~N} \times 6.25$ (Hiller et al., 1948). Potassium uptake by the test crop was calculated from the results of crop yield and nutrient (K) content in seed and stover (FRG, 2012).

Physiological efficiency (PE) was calculated according to equation-

$$
P E=\frac{Y-Y_{0}}{U-U_{0}}
$$

Where, $\mathrm{Y}$ is the economic yield of the potassium fertilized plot, $\mathrm{Y}_{0}$ is the yield of the potassium unfertilized plot, $\mathrm{U}$ is the nutrient uptake by mungbean with $\mathrm{K}$ fertilized plot and 
$\mathrm{U}_{0}$ is the nutrient uptake by mungbean with $\mathrm{K}$ unfertilized plot (Paul et al., 2014).

Apparent nutrient recovery efficiency (ANR) was calculated according to equation of

$$
\mathrm{ANR}=\frac{\left(\text { Nutrient uptake } F_{\mathrm{g}} \mathrm{kg}-\text { Nutrient uptake } C_{2} \mathrm{~kg}\right)}{\left(Q \text { uantity of nutrient applied } \mathrm{k}_{\mathrm{k}} \mathrm{kg}\right)} \times 100
$$

(Baligar et al., 2001)

An apparent potassium balance was calculated by the considering the nutrient (K) input and output (FRG, 2012). The K source was fertilizer. On the other hand, the output of $\mathrm{K}$ was calculated only from the crop uptake.

\subsection{Statistical Analysis}

Analysis of variance was conducted to determine the effects of different levels of potassium application for the yield, yield attributes, nodulation, protein content and N, P, K, S, Zn, B content, respectively and $\mathrm{K}$ uptake of the test crop during consecutive two years following the Statistix 10 package (Statistix 10., 1985). Data of yield attributes, number of nodules per plant, protein content and N, P, K, S, Zn, B content, respectively were computed average of two study years. Data of all parameters (including averaged data) were statistically analysed through ANOVA procedure using a randomized complete block design with three replicates considering block variable (replication), treatment variable and dependable variable (parameter). Then multiple comparisons like all-pairwise comparisons, i.e., the means of treatment tested by LSD method at 5\% (LSD 0.05) level of significance (Statistix 10., 1985).

\section{Results and Discussion}

\section{Yields of mungbean}

Seed yield is the key reflection for every study involving the commercial cultivation as well as the seed production of a crop. Number of pods per plant, seeds per pod, and seed weight contributed positively to obtain the higher seed yield. The results from Table 2 revealed that the application of different rates of potassium demonstrated significant effect on the seed yield of mungbean. However, the highest seed yield of mungbean (1456 kg ha ${ }^{-1}$ in 2016 and $1496 \mathrm{~kg} \mathrm{ha}^{-1}$ in 2017) was produced by $\mathrm{T}_{5}$ treatment which was significantly higher over the other treatments, but statistically identical at $\mathrm{T}_{6}$ treatment in both the years. The results are in agreement with the findings of Hussain et al. (2011). The average seed yield of mungbean (mean of two years) varied from 1058 to $1476 \mathrm{~kg} \mathrm{ha}^{-1}$. The lowest seed yield was found in $\mathrm{K}$ control treatment (Table 2). The mean seed yield further showed that the increase in seed yield ranged from 11.2 to $39.5 \%$ at different treatments compared to the K control treatment. Chaudhari et al. (2018) observed that potassium application influenced significant increase in grain yield of black gram in all the treatments over control. This indicates the fact that potassium application might be involved in activation of enzymes, related to starch synthesis, $\mathrm{N}$ metabolism and respiration, translocation of sugars from leaves to other parts, regulation of stomatal openings and imparts disease resistance to plants. The plot lacking in potassium $\left(\mathrm{T}_{1}\right)$ showed lower yield than other treatments where K was applied. Srinivasarao et al. (2003) reported that the grain yield of pulses significantly responses to $\mathrm{K}$ application. Regarding 
stover yield of mungbean, it was showed almost similar trend of seed yield. The average stover yield of mungbean (mean of two years) varied from 2355 to $3090 \mathrm{~kg} \mathrm{ha}^{-1}$. The highest stover yield was found in $\mathrm{T}_{5}$ followed by $\mathrm{T}_{6}$ treatment (Table 2 ). The result is supported by Hussain et al. (2016) who reported that the stover yield of mungbean was recorded higher $\left(4926 \mathrm{~kg} \mathrm{ha}^{-1}\right)$ in plots receiving the higher potash levels.

Table 2. Influence of different levels of potassium on seed and stover yield of mungbean

\begin{tabular}{lcccccc}
\hline & \multicolumn{5}{c}{ Seeds yield $\left(\mathrm{kg} \mathrm{ha}^{-1}\right)$} & \multicolumn{3}{c}{ Stover yield $\left(\mathrm{kg} \mathrm{ha}^{-1}\right)$} \\
\hline Treatment & 2016 & 2017 & mean & 2016 & 2017 & mean \\
\hline $\mathrm{T}_{1}=$ Control & $1083 \mathrm{~d}$ & $1032 \mathrm{~d}$ & 1058 & $2443 \mathrm{~d}$ & $2266 \mathrm{~d}$ & 2355 \\
$\mathrm{~T}_{2}=30.0 \quad \mathrm{~K} \mathrm{~kg} \mathrm{ha}^{-1}$ & $1145 \mathrm{~d}$ & $1208 \mathrm{c}$ & 1177 & $2582 \mathrm{~cd}$ & $2478 \mathrm{~cd}$ & 2530 \\
$\mathrm{~T}_{3}=40.0 \mathrm{~kg} \mathrm{~K} \mathrm{ha}^{-1}$ & $1278 \mathrm{c}$ & $1284 \mathrm{bc}$ & 1281 & $2742 \mathrm{bc}$ & $2677 \mathrm{bc}$ & 2710 \\
$\mathrm{~T}_{4}=50.0 \mathrm{~kg} \mathrm{~K} \mathrm{ha}^{-1}$ & $1351 \mathrm{bc}$ & $1316 \mathrm{bc}$ & 1334 & $2908 \mathrm{ab}$ & $2746 \mathrm{abc}$ & 2827 \\
$\mathrm{~T}_{5}=60.0 \mathrm{~kg} \mathrm{~K} \mathrm{ha}^{-1}$ & $1456 \mathrm{a}$ & $1496 \mathrm{a}$ & 1476 & $3119 \mathrm{a}$ & $3061 \mathrm{a}$ & 3090 \\
$\mathrm{~T}_{6}=70.0 \mathrm{~kg} \mathrm{~K} \mathrm{ha}^{-1}$ & $1423 \mathrm{ab}$ & $1437 \mathrm{ab}$ & 1430 & $3099 \mathrm{a}$ & $2997 \mathrm{ab}$ & 3048 \\
$\mathrm{CV}(\%)$ & 4.08 & 7.36 & - & 4.13 & 6.82 & - \\
$\mathrm{LSD}(0.05)$ & 95.8 & 173 & - & 211 & 335 & - \\
\hline
\end{tabular}

Values within the same column with a common letter do not differ significantly $(\mathrm{P}<0.05)$

Yield contributing characters of mungbean

Yield contributing characters (plant height, pods per plant, seed weight etc.) are most influential and important part, and most closely associated to get higher seed yield of mungbean. However, yield contributing characters of mungbean were influenced significantly due to different levels of potassium. Plant height is the morpho-physiological feature which acts as a key to shoot yield as well as total biomass production. Results of the Table 3 exposed that the tallest plant $(48.9 \mathrm{~cm})$ was found in $\mathrm{T}_{6}$ treatment which showed statistically indentical at $T_{5}$ and $T_{4}$ treatments but significantly higher over the other treatments. The result is in agreement with the findings of Hussain et al. (2011) who observed that maximum plant height of mungbean $(49.9 \mathrm{~cm})$ obtained in application of $90 \mathrm{~kg} \mathrm{~K} \mathrm{ha}{ }^{-1}$. The dwarf plant $(43.6 \mathrm{~cm}$ ) was obtained in $\mathrm{K}$ control plot which might be due to the reason that root shoot ratio is associated with potassium uptake (Yang et al., 2004). The highest number of primary branches per plant (3.27) was found in the treatment $\mathrm{T}_{6}$ which was significantly higher over the other treatments while it was statistically similar to $\mathrm{T}_{5}$ and $\mathrm{T}_{4}$ 


\section{Ml Macrothink}

Journal of Agricultural Studies

ISSN 2166-0379

2019, Vol. 7, No. 1

treatments and lowest was in K control $\left(\mathrm{T}_{1}\right)$ treatment. Similar finding was recorded by Tariq et al. (2001).

Potassium application was favourably influenced on pod length of mungbean. The longest pod $(8.73 \mathrm{~cm})$ was observed in $T_{5}$ followed by $T_{6}$ and $T_{4}$ treatment whereas the short pod length $(7.67 \mathrm{~cm})$ was found in $\mathrm{K}$ control $\left(\mathrm{T}_{1}\right)$ plot (Table 3$)$. This finding is in partial agreement with the results of Sultana et al. (2009).

The number of pods per plant is the most prominent attribute for achieving higher yield. The different rates of potassium contributed significantly to obtain higher number of pods per plant. The maximum number of pods per plant (26.6) was recorded from the treatment $\mathrm{T}_{5}$ which was significantly higher over the others treatments but statistically similar to the treatments of $\mathrm{T}_{6}$ and $\mathrm{T}_{4}$, while the lowest (19.4) was observed in $\mathrm{T}_{1}$ treatment (Table 3). Similar findings were corroborated by Saket Kumar et al. (2018) who reported that maximum number of pods per plant was 26.7 obtained when potash applied at $90 \mathrm{~kg}$ per hectare. The number of seeds per pod was affected significantly by the application of different levels potassium. Hence the highest number of seeds per pod (10.6) was recorded from the $T_{5}$ which was showed significantly different over the other treatments but statistically similar to $\mathrm{T}_{6}$. The highest number of seeds per pod might be obtained due to different rates of potassium application, for the reason that potassium enhanced the protein synthesis which enhanced the production of maximum number of seeds per pod. These results are in accordance with those of (Thalooth et al., 2006) who concluded that the interactive effect of potassium application and irrigation had significant effect on number of seeds per pod of mungbean.

Seed weight is an important quality attribute of crops. Seed weight might be genetically controlled, the growing condition and nutrient management exerts significant influence on its expression. However, the highest 1000 seed weight $\left(49.4 \mathrm{~g}\right.$ ) was recorded from the treatment $\mathrm{T}_{5}$ that was significantly different with the other treatments but statistically identical at $\mathrm{T}_{6}$ and $\mathrm{T}_{4}$ treatments, while the lowest 1000 seed weight was in control treatment (Table 3). Highest 1000-grain weight was obtained due to different rates of potassium application, whereas potassium might be increased photosynthates translocation from source to sinks and also enhanced availability of other nutrients (Sadaf and Tahir, 2017). 
Table 3. Influence of different levels of potassium on yield contributing characters of mungbean (Pooled data of two years)

\begin{tabular}{|c|c|c|c|c|c|c|}
\hline Treatment & $\begin{array}{l}\text { Plant } \\
\text { height } \\
(\mathrm{cm})\end{array}$ & $\begin{array}{l}\text { No. of } \\
\text { branch } \\
\text { plant }^{-1}\end{array}$ & $\begin{array}{l}\text { Pod length } \\
\text { (cm) }\end{array}$ & $\begin{array}{l}\text { No. of pods } \\
\text { plant }^{-1}\end{array}$ & $\begin{array}{c}\text { No. of } \\
\text { seeds pod }^{-1}\end{array}$ & $\begin{array}{c}\text { Thousand seed } \\
\text { wt }(\mathrm{g})\end{array}$ \\
\hline $\mathrm{T}_{1}=$ Control & $43.6 \mathrm{c}$ & $2.27 \mathrm{~d}$ & $7.67 \mathrm{~d}$ & $19.4 d$ & $8.20 \mathrm{~d}$ & $46.3 \mathrm{~d}$ \\
\hline $\begin{array}{c}\mathrm{T}_{2}=30.0 \quad \mathrm{~K} \\
\mathrm{~kg} \mathrm{ha}^{-1}\end{array}$ & $45.6 \mathrm{bc}$ & $2.57 \mathrm{c}$ & $7.94 \mathrm{~cd}$ & $22.3 \mathrm{c}$ & $9.47 \mathrm{c}$ & $47.1 \mathrm{~cd}$ \\
\hline $\begin{array}{c}\mathrm{T}_{3}=40.0 \mathrm{~kg} \mathrm{~K} \\
\mathrm{ha}^{-1}\end{array}$ & $46.3 b$ & $2.93 b$ & $8.20 \mathrm{bc}$ & $23.5 b c$ & $9.67 \mathrm{bc}$ & $47.8 \mathrm{bc}$ \\
\hline $\begin{array}{c}\mathrm{T}_{4}=\underset{\mathrm{ha}^{-1}}{50.0 \mathrm{~kg} \mathrm{~K}} \\
\end{array}$ & 46.9ab & $3.10 \mathrm{ab}$ & $8.43 \mathrm{ab}$ & $24.5 \mathrm{abc}$ & $9.86 \mathrm{~b}$ & $48.6 \mathrm{ab}$ \\
\hline $\begin{array}{c}\mathrm{T}_{5}=\underset{\mathrm{ha}^{-1}}{60.0 \mathrm{~kg} \mathrm{~K}} \\
\end{array}$ & $48.4 \mathrm{a}$ & $3.20 \mathrm{a}$ & $8.73 a$ & $26.6 \mathrm{a}$ & $10.6 \mathrm{a}$ & $49.4 \mathrm{a}$ \\
\hline $\begin{array}{c}\mathrm{T}_{6}=\underset{\mathrm{ha}^{-1}}{70.0 \mathrm{~kg} \mathrm{~K}} \\
\end{array}$ & $48.9 \mathrm{a}$ & $3.27 \mathrm{a}$ & $8.60 \mathrm{a}$ & $26.3 \mathrm{ab}$ & $10.4 \mathrm{a}$ & $49.1 \mathrm{ab}$ \\
\hline $\mathrm{CV}(\%)$ & 2.43 & 4.88 & 2.22 & 6.40 & 1.79 & 1.56 \\
\hline LSD (0.05) & 2.06 & 0.26 & 0.34 & 2.77 & 0.32 & 1.37 \\
\hline
\end{tabular}

Values within the same column with a common letter do not differ significantly $(\mathrm{P}<0.05)$

Effects of potassium on $N, P, K, S, Z n$, and B content of mungbean

The content of N, P, K, S, Zn, and B in mungbean (seed and stover) was markedly influenced by the application of different levels of potassium (Tables 4 and 5). The results showed that different potassium treatments had a significant influence on the $\mathrm{N}$ content in mungbean (seed and stover). The highest $\mathrm{N}$ content (3.47\% in seed and $1.64 \%$ in stover) was obtained from the $\mathrm{T}_{5}$ treatment, which was statistically similar to $\mathrm{T}_{6}, \mathrm{~T}_{4}$ and $\mathrm{T}_{3}$ in seed and it was showed significantly variation over the other treatments in stover of mungbean, while the lowest $\mathrm{N}$ content $\left(3.23 \%\right.$ in seed and $1.41 \%$ in stover) was obtained from the $\mathrm{K}$ control $\left(\mathrm{T}_{1}\right)$ treatment (Tables 4 and 5). It has been documented that the different levels of potassium application in mungbean field conditions increase biological $\mathrm{N}_{2}$ fixation through nodulation process, resulting in higher $\mathrm{N}$ content in seed and stover of mungbean. This result is in close similarity with Srinivasarao et al. (2003) and Asgar et al. (2006).

In case of $\mathrm{P}$ content, the highest $\mathrm{P}$ content $(0.45 \%)$ in seed was obtained from the treatment $\mathrm{T}_{5}$, which was significantly different with the other treatments but statistically identical at per $\mathrm{T}_{6}$ treatment. The highest $\mathrm{P}$ content in mungbean stover $(0.25 \%)$ was also obtained in $\mathrm{T}_{5}$ treatment which was statistically similar to $\mathrm{T}_{6}$ and $\mathrm{T}_{4}$ treatment. The lowest $\mathrm{P}$ content in mungbean $\left(0.39 \%\right.$ in seed and $0.18 \%$ in stover) was observed in $\mathrm{T}_{1}$ (control) treatment (Tables 4 and 5). This result was in agreement with the findings of Pranav Kumar et al. (2014) and Singh et al. (2002).

The content of potassium in mungbean considerably increased with increasing potassium levels. Highest content of potassium (1.62\%) in seed was observed in $\mathrm{T}_{6}$ treatment which was statistically similar to $\mathrm{T}_{5}, \mathrm{~T}_{4}, \mathrm{~T}_{3}$ and $\mathrm{T}_{2}$ treatments, while minimum potassium content $(1.43 \%)$ in seed was found in $\mathrm{K}$ control $\left(\mathrm{T}_{1}\right)$ treatment. The highest $\mathrm{K}$ content in stover of mungbean (2.44\%) was also observed in $\mathrm{T}_{6}$ which was statistically identical with $\mathrm{T}_{5}$ and $\mathrm{T}_{4}$ treatments, 


\section{Macrothink}

however the lowest $\mathrm{K}$ content in stover $(2.12 \%)$ was in control $\left(\mathrm{T}_{1}\right)$ treatment (Table 4 and 5). The previous experiment had shown that $\mathrm{K}$ content remarkably increased with increasing potassium levels. Highest K content (1.86\%) in mungbean was observed in the plot receiving of $125 \mathrm{~kg} \mathrm{~K} \mathrm{ha}^{-1}$ (Jamil et al., 2018). The $\mathrm{S}$ content in both seed and stover of mungbean was increased due to $\mathrm{K}$ applications to the soil. The highest $\mathrm{S}$ content in mungbean $(0.13 \%$ in seed and $0.10 \%$ in stover) was found in $\mathrm{T}_{5}$ followed by $\mathrm{T}_{4}$ and $\mathrm{T}_{6}$ treatments, while the lowest $\mathrm{S}$ content $(0.09 \%$ in seed and $0.07 \%$ in stover $)$ was found in $\mathrm{K}$ control $\left(\mathrm{T}_{1}\right)$ treatment.

Potassium plays a significant role for accumulation of $\mathrm{Zn}$ and $\mathrm{B}$ in mungbean plant. The highest $\mathrm{Zn}$ content in mungbean (27.1 ppm in seed and $30.1 \mathrm{ppm}$ in stover) was obtained from the $T_{5}$ treatment, which was statistically similar to $T_{6}$ and $T_{4}$. The lowest $\mathrm{Zn}$ content (21.3 ppm in seed and $26.4 \mathrm{ppm}$ in stover) was however obtained from the control $\left(\mathrm{T}_{1}\right)$ treatment. The highest B content in mungbean (22.7 ppm in seed and $21.9 \mathrm{ppm}$ in stover) was recorded from the $T_{5}$ treatment, which was statistically similar to $T_{4}, T_{6}$ and $T_{3}$ in seed while it was statistically similar to $\mathrm{T}_{6}$ and $\mathrm{T}_{4}$ in stover of mungbean. The lowest $\mathrm{Zn}$ and $\mathrm{B}$ contents (seed and stover) were obtained from control $\left(\mathrm{T}_{1}\right)$ treatment (Tables 4 and 5). It has been documented that nodulation and quality control of legume crops are closely related to plant growth itself. Micronutrients such as Zn and B remarkably influenced on seed quality and nodulation process, however the levels of $\mathrm{K}$ regulated the $\mathrm{Zn}$ and $\mathrm{B}$ content in legume crops (Mirza Hasanuzzaman et al., 2018).

The protein content of mungbean under different levels of potassium is presented in Table 4. The results of protein content showed significant variation across the different treatments. The highest protein content $21.7 \%$ was obtained in $\mathrm{T}_{5}$ treatment which was statistically similar to $\mathrm{T}_{4}(21.6 \%), \mathrm{T}_{6}(21.5 \%)$ and $\mathrm{T}_{3}(21.3 \%)$ treatments, although the lowest protein content $(20.2 \%)$ was in control $\left(\mathrm{T}_{1}\right)$ treatments. Potassium involved in physiological and biochemical functions of plant growth i.e. enzyme activation and protein synthesis and its application in legumes might have improved the nitrogen use efficiency which leads to increase the protein content of the crop. Kurhade et al. (2015) reported that seed protein content was obtained maximum in case of $\mathrm{RDF}+40 \mathrm{Kg} \mathrm{K}_{2} \mathrm{O} \mathrm{ha}^{-1}(22.16 \%)$. The results are supported by Hussain et al. (2011); Farad et al. (2010) in soybean; Thesiya et al. (2013) in blackgram. 


\section{Macrothink}

Journal of Agricultural Studies

ISSN 2166-0379

2019, Vol. 7, No. 1

Table 4. Influence of different levels of potassium on N, P, K, S, Zn, B and protein content in seed of mungbean (Pooled data of two years)

\begin{tabular}{|c|c|c|c|c|c|c|c|}
\hline Treatment & $\mathrm{N}$ & $\mathrm{P}$ & $\mathrm{K}$ & $S$ & $\begin{array}{l}\mathrm{Zn} \\
\quad \mathrm{pp}\end{array}$ & B & $\begin{array}{c}\text { Protein content } \\
\%\end{array}$ \\
\hline $\mathrm{T}_{1}=$ Control & $3.23 \mathrm{c}$ & $0.39 \mathrm{e}$ & $1.43 b$ & $0.09 \mathrm{~d}$ & $21.3 \mathrm{~d}$ & $20.3 b$ & $20.2 \mathrm{c}$ \\
\hline $\mathrm{T}_{2}=30.0 \quad \mathrm{~K} \mathrm{~kg} \mathrm{ha}^{-1}$ & $3.35 b$ & $0.41 \mathrm{~d}$ & $1.50 \mathrm{ab}$ & $0.10 \mathrm{~cd}$ & $23.6 \mathrm{c}$ & $21.9 \mathrm{ab}$ & $20.9 b$ \\
\hline $\mathrm{T}_{3}=40.0 \mathrm{~kg} \mathrm{~K} \mathrm{ha}^{-1}$ & $3.41 \mathrm{ab}$ & $0.42 \mathrm{~cd}$ & $1.54 \mathrm{ab}$ & $0.11 b c$ & $25.0 \mathrm{bc}$ & $22.1 \mathrm{a}$ & $21.3 \mathrm{ab}$ \\
\hline $\mathrm{T}_{4}=50.0 \mathrm{~kg} \mathrm{~K} \mathrm{ha}^{-1}$ & $3.45 \mathrm{a}$ & $0.43 b c$ & $1.57 \mathrm{a}$ & $0.12 \mathrm{ab}$ & $26.3 \mathrm{ab}$ & $22.6 a$ & $21.6 a$ \\
\hline $\mathrm{T}_{5}=60.0 \mathrm{~kg} \mathrm{~K} \mathrm{ha}^{-1}$ & $3.47 \mathrm{a}$ & $0.45 \mathrm{a}$ & $1.59 \mathrm{a}$ & $0.13 \mathrm{a}$ & $27.1 \mathrm{a}$ & $22.7 \mathrm{a}$ & $21.7 \mathrm{a}$ \\
\hline $\mathrm{T}_{6}=70.0 \mathrm{~kg} \mathrm{~K} \mathrm{ha}^{-1}$ & $3.44 \mathrm{a}$ & $0.44 \mathrm{ab}$ & $1.62 \mathrm{a}$ & $0.12 \mathrm{ab}$ & $26.9 \mathrm{ab}$ & $22.4 \mathrm{a}$ & $21.5 \mathrm{a}$ \\
\hline $\mathrm{CV}(\%)$ & 1.41 & 2.32 & 4.45 & 7.49 & 4.28 & 4.43 & 1.46 \\
\hline LSD (0.05) & 0.09 & 0.02 & 0.13 & 0.02 & 1.95 & 1.77 & 0.57 \\
\hline
\end{tabular}

Values within the same column with a common letter do not differ significantly $(\mathrm{P}<0.05)$

Table 5. Influence of different levels of potassium on N, P, K, S, Zn and B contents in stover of mungbean (Pooled data of two years)

\begin{tabular}{lcccc|cc}
\hline \multicolumn{1}{c}{ Treatment } & $\mathrm{N}$ & $\mathrm{P}$ & $\mathrm{K}$ & $\mathrm{S}$ & \multicolumn{2}{c}{$\mathrm{Zn}$} \\
\hline $\mathrm{T}_{1}=$ Control & $1.41 \mathrm{~d}$ & $0.18 \mathrm{~d}$ & $2.12 \mathrm{~d}$ & $0.07 \mathrm{~d}$ & $26.4 \mathrm{c}$ & $19.3 \mathrm{~d}$ \\
$\mathrm{~T}_{2}=30.0 \quad \mathrm{~K} \mathrm{~kg} \mathrm{ha}^{-1}$ & $1.49 \mathrm{c}$ & $0.21 \mathrm{c}$ & $2.21 \mathrm{~cd}$ & $0.08 \mathrm{c}$ & $27.8 \mathrm{~b}$ & $20.1 \mathrm{~cd}$ \\
$\mathrm{~T}_{3}=40.0 \mathrm{~kg} \mathrm{~K} \mathrm{ha}^{-1}$ & $1.52 \mathrm{bc}$ & $0.22 \mathrm{bc}$ & $2.29 \mathrm{bc}$ & $0.08 \mathrm{c}$ & $28.3 \mathrm{~b}$ & $20.4 \mathrm{bcd}$ \\
$\mathrm{T}_{4}=50.0 \mathrm{~kg} \mathrm{~K} \mathrm{ha}^{-1}$ & $1.55 \mathrm{bc}$ & $0.23 \mathrm{abc}$ & $2.36 \mathrm{ab}$ & $0.09 \mathrm{~b}$ & $29.7 \mathrm{a}$ & $21.3 \mathrm{abc}$ \\
$\mathrm{T}_{5}=60.0 \mathrm{~kg} \mathrm{~K} \mathrm{ha}^{-1}$ & $1.64 \mathrm{a}$ & $0.25 \mathrm{a}$ & $2.40 \mathrm{ab}$ & $0.10 \mathrm{a}$ & $30.1 \mathrm{a}$ & $21.9 \mathrm{a}$ \\
$\mathrm{T}_{6}=70.0 \mathrm{~kg} \mathrm{~K} \mathrm{ha}^{-1}$ & $1.56 \mathrm{~b}$ & $0.24 \mathrm{ab}$ & $2.44 \mathrm{a}$ & $0.08 \mathrm{c}$ & $29.8 \mathrm{a}$ & $21.6 \mathrm{ab}$ \\
$\mathrm{CV}(\%)$ & 2.44 & 5.27 & 3.23 & 6.20 & 2.54 & 3.26 \\
LSD $(0.05)$ & 0.07 & 0.02 & 0.14 & $9.4 \mathrm{E}-03$ & 1.33 & 1.23 \\
\hline
\end{tabular}

Values within the same column with a common letter do not differ significantly $(\mathrm{P}<0.05)$

Number of nodules per plant and potassium uptake by mungbean

Nodulation of mungbean was affected significantly due to application of different levels of potassium (Figure 1). From the result in 45 days after sowing, however the number of nodules per plant varied from 24.2 to 36.4 across the treatments. The result indicated that 
potassium has a vital role for nodule formation. The maximum number of nodules per plant (36.4) was recorded from the treatment $T_{5}$ which was statistically alike to $T_{6}(35.5)$ and $T_{4}$ (34.1) while the lowest number of nodules per plant (24.2) was obtained from control $\left(\mathrm{T}_{1}\right)$ treatment (Figure 1). This finding was supported by Kurdali et al. (2002) in chickpea and Pranav Kumar (2014). It has been reported that adequate supply of potassium in soil improves the water relations of plant and photosynthesis, helps in osmotic-regulation of plant cell, assists in opening and closing of stomata, activates the enzymes, nodulation and synthesizes the protein (Grag et al., 2005; Yang et al., 2004).

Different rates of potassium contributed significantly to obtain higher uptake of potassium by mungbean (seed+stover) over control (Figure 1). However the total uptake of K by mungbean (seed+stover) ranged from 65.5 to $98.4 \mathrm{~kg} \mathrm{ha}^{-1}$ across the treatments whereas the highest uptake of $\mathrm{K}\left(98.4 \mathrm{~kg} \mathrm{ha}^{-1}\right)$ was observed in $\mathrm{T}_{5}$ followed by $\mathrm{T}_{6}\left(97.9 \mathrm{~kg} \mathrm{ha}^{-1}\right)$ treatment. The lowest uptake of $\mathrm{K}\left(65.5 \mathrm{~kg} \mathrm{ha}^{-1}\right)$ was found in control $\left(\mathrm{T}_{1}\right)$ treatment (Figure 1).

Since uptake of nutrient $(\mathrm{K})$ is a function of their content and yield, increase in seed and stover yield along with higher content of $\mathrm{K}$ might have resulted in higher uptake of this nutrient in the crop. Similar observation was documented by Narendra Kumawat et al. (2009).
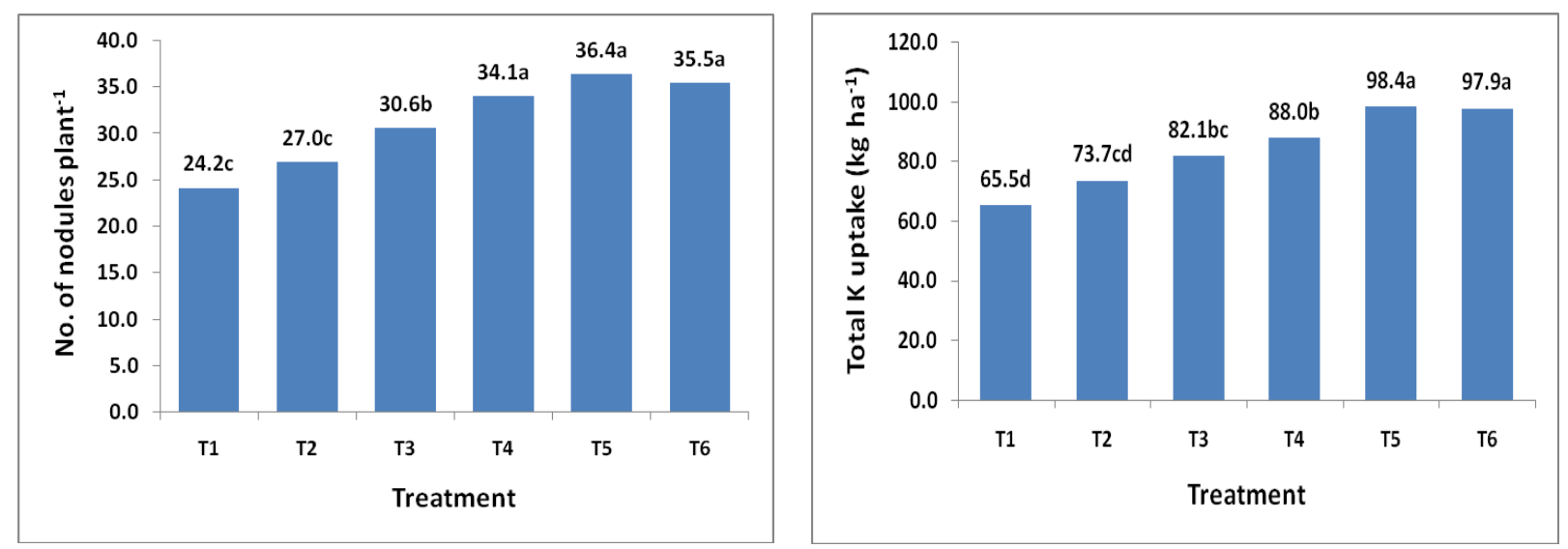

Figure 1. Effects of different levels of $\mathrm{K}$ on number of nodules per plant and total $\mathrm{K}$ uptake by mungbean. Averages from two independent experiments are shown

Mean followed by the uncommon letters are significantly differ from each other at $5 \%$ level of significance

Note: $\mathrm{T}_{1}=$ Control, $\mathrm{T}_{2}=30 \mathrm{~kg} \mathrm{~K} \mathrm{ha}^{-1}, \mathrm{~T}_{3}=40 \mathrm{~kg} \mathrm{~K} \mathrm{ha}^{-1}, \mathrm{~T}_{4}=50 \mathrm{~kg} \mathrm{~K} \mathrm{ha}^{-1}, \mathrm{~T}_{5}=60 \mathrm{~kg} \mathrm{~K} \mathrm{ha}^{-1}$ and $\mathrm{T}_{6}=70 \mathrm{~kg} \mathrm{~K} \mathrm{ha}^{-1}$

Physiological efficiency $(P E)$ and apparent nutrient recovery efficiency (ANR) of $K$ in mungbean

The nutrient use efficiency (NUE) assessment is helpful to differentiate plant species, genotypes and cultivars for their ability to absorb and utilize nutrients for maximum yields. 
Some tools are commonly used for understanding the nutrient use efficiency (NUE) such as physiological efficiency (PE) and apparent nutrient recovery efficiency (ANR). Physiological efficiency (PE) refers to the ability of a plant to transform a given amount of an acquired nutrient into grain yield. It refers to the grain yield per unit nutrient uptake. Apparent nutrient recovery efficiency (ANR) refers to reflect the plant ability to acquire applied nutrient from soil (FRG, 2012; Baligar et al., 2001). The physiological efficiency (PE) was affected significantly by the application of different levels of $\mathrm{K}$ (Figure 2). The physiological efficiency (PE) of $\mathrm{K}$ in mungbean ranged from 47.1 to $49.6 \mathrm{~kg} \mathrm{~kg}^{-1}$ across the different rates of $\mathrm{K}$. The highest PE of $\mathrm{K}\left(49.6 \mathrm{~kg} \mathrm{~kg}^{-1}\right)$ was recorded from the treatment $\mathrm{T}_{2}$ followed by $\mathrm{T}_{3}$ (49.5 kg kg $\mathrm{kg}^{-1}$ ) and $\mathrm{T}_{5}\left(49.2 \mathrm{~kg} \mathrm{~kg}^{-1}\right)$ treatments while the lowest $\mathrm{PE}\left(47.1 \mathrm{~kg} \mathrm{~kg}^{-1}\right)$ was recorded from $\mathrm{T}_{6}$ treatment (Figure 2). Application of different rates of potassium demonstrated positive effect on apparent nutrient (K) recovery efficiency (ANR) of mungbean (Figure 2). Results revealed that the the highest apparent nutrient (K) recovery efficiency $\left(54.8 \%\right.$ ) was found in $\mathrm{T}_{5}$ however the lowest ANR eifficiency of $\mathrm{K}(27.3 \%)$ was in $\mathrm{T}_{2}$ treatment (Figure 2). It might be seemed that nutrient absorption power of the crops depended upon their utilization at the biochemical levels, crops may be varied in the recovery of the applied nutrients. The high variability of apparent nutrient recovery may be attributed to the growing environment, seasonal variability and fertilizer management that affect yield of crops. Similar observation was documented by Salam et al. (2014) in rice based cropping system.
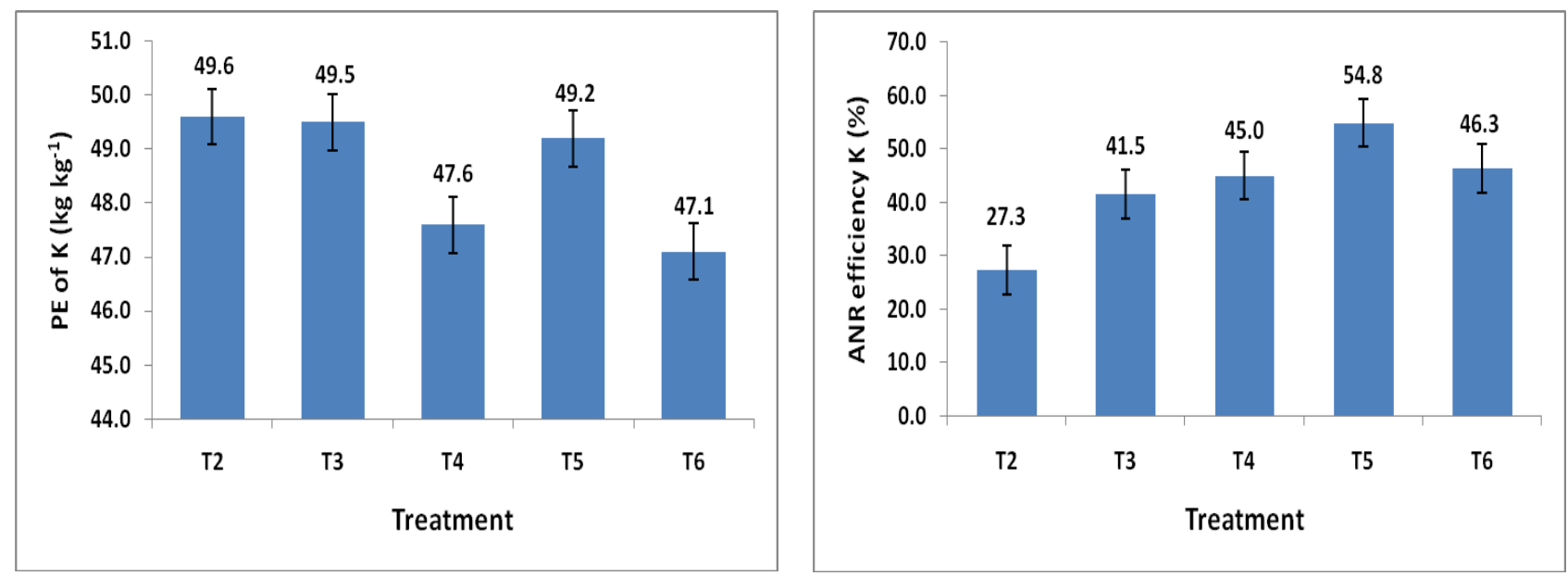

Figure 2. Effects of different levels of $\mathrm{K}$ on physiological efficiency of $\mathrm{K}$ and apparent nutrient $(\mathrm{K})$ recovery efficiency $(\%)$ by mungbean. Averages from two independent experiments are shown. Error bars represent the SEM

Note: $\mathrm{T}_{1}=$ Control, $\mathrm{T}_{2}=30 \mathrm{~kg} \mathrm{~K} \mathrm{ha}^{-1}, \mathrm{~T}_{3}=40 \mathrm{~kg} \mathrm{~K} \mathrm{ha}^{-1}, \mathrm{~T}_{4}=50 \mathrm{~kg} \mathrm{~K} \mathrm{ha}^{-1}, \mathrm{~T}_{5}=60 \mathrm{~kg} \mathrm{~K} \mathrm{ha}^{-1}$ and $\mathrm{T}_{6}=70 \mathrm{~kg} \mathrm{~K} \mathrm{ha}^{-1}$

\section{Effect of different levels of $K$ on apparent nutrient $(K)$ balance}

Calculation of apparent nutrient $(\mathrm{K})$ balance has been made allowing the amount of added $\mathrm{K}$ through fertilizer minus the amount of $\mathrm{K}$ removed by the test crop. However, the apparent 
balance of $\mathrm{K}$ is shown in Figures 3. Different $\mathrm{K}$ application rates have contributed significantly to change the apparent $\mathrm{K}$ balance in soil. Results revealed that, apparent $\mathrm{K}$ balance was negative in all the treatment and the depletion ranged from -27.9 to $-65.5 \mathrm{~kg} \mathrm{~K}$ $\mathrm{ha}^{-1}$. The greatest $\mathrm{K}$ mining $\left(-65.5 \mathrm{~kg} \mathrm{ha}^{-1}\right)$ was measured from $\mathrm{K}$ control $\left(\mathrm{T}_{1}\right)$ while the second highest $\mathrm{K}$ mining (-43.7 $\mathrm{kg} \mathrm{ha}^{-1}$ ) was obtained from $\mathrm{T}_{2}$ followed by $\mathrm{T}_{3}\left(-42.1 \mathrm{~kg} \mathrm{ha}^{-1}\right)$ treatment and the lowest $\mathrm{K}$ mining $\left(-27.9 \mathrm{~kg} \mathrm{ha}^{-1}\right)$ was estimated in $\mathrm{T}_{6}$ treatment. Seasonal (summer) impact on nutrient balance was marked with $\mathrm{K}$ application although negative $\mathrm{K}$ balance was noted across the treatments (Figure 3). The higher negative apparent K balances in mungbean were related to the $\mathrm{K}$ control or lower $\mathrm{K}$ application rate, while the lower negative apparent $\mathrm{K}$ balances in mungbean were related to the higher $\mathrm{K}$ application rate. Furthermore, higher magnitude of net negative $\mathrm{K}$ balance depends on soil types, seasons and amount of nutrient (K) application. Similar observation was noted by Chitdeshwari et al. (2011) and Huimin Zhang et al. (2010) in rice based cropping system.

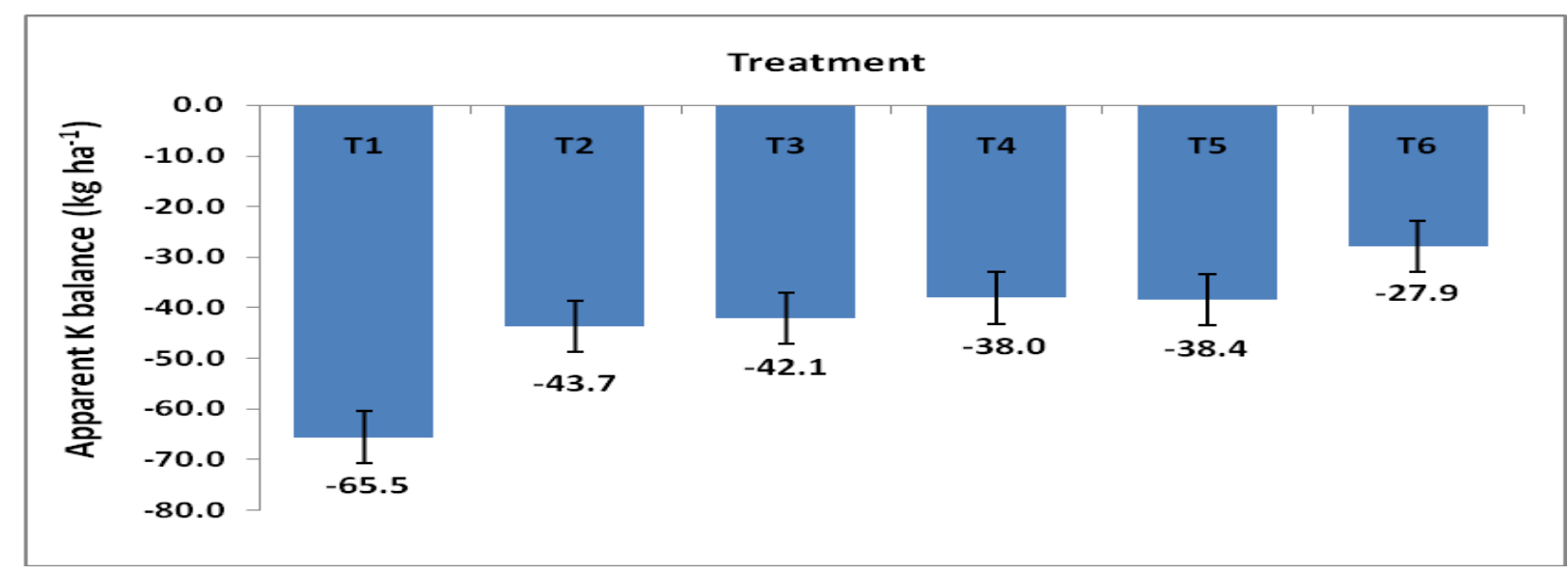

Figure 3. Effects of different levels of $\mathrm{K}$ on apparent balance of $\mathrm{K}$ in soil by mungbean. Averages from two independent experiments are shown. Error bars represent the SEM

Note: $\mathrm{T}_{1}=$ Control, $\mathrm{T}_{2}=30 \mathrm{~kg} \mathrm{~K} \mathrm{ha}^{-1}, \mathrm{~T}_{3}=40 \mathrm{~kg} \mathrm{~K} \mathrm{ha}^{-1}, \mathrm{~T}_{4}=50 \mathrm{~kg} \mathrm{~K} \mathrm{ha}^{-1}, \mathrm{~T}_{5}=60 \mathrm{~kg} \mathrm{~K} \mathrm{ha}^{-1}$ and $\mathrm{T}_{6}=70 \mathrm{~kg} \mathrm{~K} \mathrm{ha}^{-1}$

\section{Effect of different levels of $K$ on postharvest soils properties}

Postharvest soil properties were affected by the application of different rates of potassium (Table 6). Initially the soil $\mathrm{pH}$ was 8.2 , but after completion of 2 consecutive years of experiments, the soil $\mathrm{pH}$ remained unchanged or slightly increased due to the different $\mathrm{K}$ treatments. Incorporation of mungbean stover into soil might increase organic matter resulted higher $\mathrm{pH}$ status by improving the soil buffering capacity (Ogbodo, 2011). Different rates of $\mathrm{K}$ tended to maintain the initial fertility or increased slightly of soil organic matter, $\mathrm{N}, \mathrm{P}, \mathrm{S}$, $\mathrm{Zn}$ and $\mathrm{B}$. In most of the cases, the highest amount of organic matter, N, P, K, S, Zn and B contents in soil was recorded from the $\mathrm{T}_{5}$ followed by $\mathrm{T}_{6}$ treatment and the lowest was from the $\mathrm{T}_{1}$ treatment (Table 6). The observation on post harvest soil properties, pulse crop (mungbean) might be helped to enrich and conserving the soil quality for enhancing the yield of next crop. Similar observation was made by Musinguzi et al. (2010). The presence of pulses in agro-ecosystems helps to maintain vital microbial biomass and activity in the soil, 
in that way nourishing those organisms that are responsible for promoting soil structure and nutrient availability (Blanchart et al. 2005).

Table 6. Effect of different levels of potassium on postharvest soil properties

\begin{tabular}{|c|c|c|c|c|c|c|c|c|c|c|}
\hline \multirow{2}{*}{ Treatment } & \multirow{2}{*}{\multicolumn{2}{|c|}{$\mathrm{pH} \mathrm{OM}(\%)$}} & \multirow{2}{*}{ Total N (\%) } & $\mathrm{Ca}$ & $\mathrm{Mg}$ & $\mathrm{K}$ & $\mathrm{P}$ & $S$ & $\mathrm{Zn}$ & B \\
\hline & & & & \multicolumn{3}{|c|}{ meq. $100 \mathrm{~g}^{-1}$} & \multicolumn{4}{|c|}{$\mu \mathrm{g} \mathrm{g}^{-1}$} \\
\hline Initial & 18.2 & 1.61 & 0.073 & 18.0 & 1.75 & 0.12 & 14.6 & 15.5 & 0.80 & 0.16 \\
\hline $\mathrm{T}_{1}=$ Control & 8.1 & 1.65 & 0.075 & 16.2 & 1.68 & 0.10 & 14.6 & 15.4 & 0.82 & 0.17 \\
\hline $\mathrm{T}_{2}=30.0 \mathrm{~kg} \mathrm{~K} \mathrm{ha}^{-1}$ & ${ }^{1} 8.2$ & 1.66 & 0.074 & 16.5 & 1.69 & 0.11 & 14.9 & 15.5 & 0.83 & 0.17 \\
\hline $\mathrm{T}_{3}=40.0 \mathrm{~kg} \mathrm{~K} \mathrm{ha}^{-1}$ & ${ }^{1} 8.2$ & 1.65 & 0.075 & 16.6 & 1.70 & 0.12 & 15.0 & 15.9 & 0.84 & 0.18 \\
\hline $\mathrm{T}_{4}=50.0 \mathrm{~kg} \mathrm{~K} \mathrm{ha}^{-1}$ & ${ }^{1} 8.3$ & 1.66 & 0.076 & 16.2 & 1.68 & 0.13 & 15.8 & 16.0 & 0.84 & 0.19 \\
\hline $\mathrm{T}_{5}=60.0 \mathrm{~kg} \mathrm{~K} \mathrm{ha}^{-1}$ & ${ }^{1} 8.3$ & 1.67 & 0.077 & 16.6 & 1.67 & 0.13 & 16.1 & 16.4 & 0.85 & 0.18 \\
\hline $\mathrm{T}_{6}=70.0 \mathrm{~kg} \mathrm{~K} \mathrm{ha}^{-1}$ & 18.3 & 1.65 & 0.075 & 16.4 & 1.63 & 0.12 & 16.0 & 16.3 & 0.86 & 0.18 \\
\hline
\end{tabular}

\section{Conclusion}

From two years study it is clear that the application in soil at the rate of $60 \mathrm{~kg} \mathrm{~K} \mathrm{ha}{ }^{-1}$ increased highest seed yield of mungbean. The potassium application contributed for obtaining more pod setting, more seeds per pod and seed weight, which ultimately enhanced the seed yield. The application of $60 \mathrm{~kg} \mathrm{~K} \mathrm{ha}^{-1}$ exhibited significant effect on the maximum number of nodules per plant, greatest nutrient content and the highest protein content in seed. Similarly K uptake and apparent K recovery efficiency were also highest in the plot receiving of $60 \mathrm{~kg} \mathrm{~K} \mathrm{ha}^{-1}$. Application of potassium showed encouraging effects on soil organic matter, total $\mathrm{N}$, available $\mathrm{P}, \mathrm{S}, \mathrm{Zn}$ and $\mathrm{B}$. Results of the present study suggested that the $60 \mathrm{~kg} \mathrm{~K} \mathrm{ha}^{-1}$ along with $\mathrm{N}_{15} \mathrm{P}_{20} \mathrm{~S}_{10} \mathrm{Zn}_{2} \mathrm{~B}_{1.5} \mathrm{~kg}$ ha ${ }^{-1}$ might be recommended for yield maximization of mungbean and sustained the fertility of calcareous soils in Bangladesh.

\section{Acknowledgement}

This research work was conducted by the financial support of Pulses Research Centre in Bangladesh Agricultural Research Institute. The authors would like to thank Dr. M.A. Quyayyum for giving valuable comments and suggestions on earlier drafts of the manuscript. Authors are grateful to the Head of Soil Science Division for providing laboratory facility to analyze the plant and soil samples. 


\section{References}

Ahmad, A. H., Bukhsh, M. A., Riaz, A., Javaid, I., Mudassar, M. M., Anser, A., ... Safdar, H. (2012). Nutritional and Physiological Significance of Potassium Application in Maize Hybrid Crop Production. Pakistan Journal of Nutrition, 11, 187-202. https://doi.org/10.3923/pjn.2012.187.202

Ali, M. A., Abbas, G., Mohy-ud-Din, Q., Ullah, K., Abbas, G., \& Aslam, M. (2010). Response of Mungbean (Vigna Radiata) to phosphatic fertilizer under arid climate. The Journal of Animal \& Plant Sciences, 20(2), 83-86.

Arif, M., Arshad, M., Khalid, A., \& Hannan, A. (2008). Differential response of rice genotypes at deficit and adequate potassium regimes under controlled conditions. Soil and Environment, 27(1), 52-57.

Asgar, A., Nadeem, M. A., Muddassar, M., \& Ejaz, M. (2006). Effect of different levels of potash on growth, yield and protein contents of mungbean varieties. Journal of Agricultural Research, 44(2), 121-126.

Baligar, V. C., Fageria, N. K., \& He, Z. L. (2001). Nutrient use efficiency in plants. Communication of Soil Science and Plant Analysis, 32(7\&8), 921-950. https://doi.org/10.1081/CSS-100104098

Barber, S. A. (1995). Soil nutrient bioavailability- a mechanistic approach ( $2^{\text {nd }}$ edition). John Willey and Sons, Inc. 182-281.

BBS (Bangladesh Bureau of statistics). 2016. Yearbook of Agriculture Statistics-2016. Statistics and Information Division, Ministry of Planning, Government of the People's Republic of Bangladesh. www.bbs.gov.bd

Black, C. A. (1965). Methods of Soil Analysis Part-II; American Society of Agronomy, Inc.: Madison, WI, USA, 770.

Blanchart, E., Villenave, C., Viallatoux, A., Barthès, B., Girardin, C., Azontonde, A., \& Feller, C. (2005). Long-term effect of a legume cover crop (Mucuna pruriens var utilis) on the communities of soil macrofauna and nematofauna under maize cultivation, in southern Benin. European Journal of Soil Biology, 42, 136-144. https://doi.org/10.1016/j.ejsobi.2006.07.018

Bremner, J. M., \& Mulvaney, C. S. (1982). Total nitrogen. In A. L. Page, R. H. Miller, D. R. Keeney (Eds.), Methods of Soil Analysis (Part 2, 2nd ed., pp. 599-622). American Society of Agronomy, Madison, USA.

Chapman, H. D., \& Pratt, P. F. (1961). Methods of analysis for soils, plants and waters. Priced Publication 4034, Barkley: University of California, Division of Agriculture Sciences.

Chaudhari, A. V., Mane, S. S., \& Chadar, B. R. (2018). Effect of graded levels of potassium on growth, yield and quality of black gram. International Journal of Current Microbiology and Applied Sciences, Special Issue-6, 1607-1612.

Chitdeshwari, T., Velu, V., \& Thilagavathy, T. (2011). Nutrient balance studies in the soils 
under intensive rice-rice system. Indian Journal of Agricultural Research, 45 (1), 11-20.

Farhad, I. S. M., Islam, M. N., Hoque, S., \& Bhuiyan, M. S. I. (2010). Role of potassium and sulphur on the growth, yield and oil content of soybean (Glycine max L.). Academic Journal of Plant Sciences, 3(2), 99-103.

Fertilizer Recommendation Guide (FRG). (2012). Fertilizer Recommendation Guide, Published by Bangladesh Agricultural Research Council, Dhaka, Bangladesh.

Fox, R. L., Olsen, R. A., \& Rhoades, H. F. (1964). Evaluating the sulphur status of soil by plant and soil test. Soil Science Society of America Proc, 28, 243-246. https://doi.org/10.2136/sssaj1964.03615995002800020034x

Garg, B. K., Burmin, U., \& Kathju, S. (2005). Physical aspects of drought tolerance in cluster bean and strategies for yield improvement under arid conditions. Journal Arid Legumes, 2, 61-66.

Gupta, K., Dey, A., \& Gupta, B. (2013). Plant polyamines in abiotic stress responses. Acta Physiologiae Plantarum, 35, 2015-2036. https://doi.org/10.1007/s11738-013-1239-4

Gupta, P. K. (2004). Soil, Plant, Water and Fertilizer Analysis. Department of Agricultural Chemistry and Soil Science, Maharana Pratap University of Agriculture \& Technology, Rajasthan, India, 168-170.

Hiller, A., Plazin, J., \& Vanslyke, D. D. (1948). A study of conditions of Kjeldhal determination of nitrogen in proteins. Journal of Biological Chemistry, 176(3), 1401-1420.

Zhang, H. M., Xu, M. G., Shi, X. J., Li, Z. Z., Huang, Q. H., \& Wang, X. J. (2010). Rice yield, potassium uptake and apparent balance under long-term fertilization in rice-based cropping systems in southern China. Nutrient Cycling in Agroecosystem, 88, 341-349. https://doi.org/10.1007/s10705-010-9359-3

Hussain, F, M., Buriro, M. R., Nizamani, S., Ahmed, S., Rehman, N. A., \& Huma, Z. (2016). Growth and yield response of Mungbean to different levels of potassium. International Journal of Agricultural and Environmental Research, 2(1), 67-76.

Hussain, F., Malik, A. U., Haji, M. A., \& Malghani, A. L. (2011). Growth and yield response of two cultivars of mungbean (vigna radiata L.) to different potassium levels. Journal of Animal \& Plant Sciences, 21(3), 622-625.

Jackson, M. L. (1973). Soil Chemical Analysis (p. 498). Prentice Hall of India Private Limited, New Delhi, India.

Jamil, M., Abbasi, G. H., Hussain, A., Malik, Z., \& Sufyan, A. (2018). Response of mungbean (vigna radiata 1.) to potassium application rates under desert climate. Pakistan Journal of Agriculture, Agricultural Engineering \& Veterinary Sciences, 34 (1), 10-21.

Kabir, M. E., Karim, M. A., \& Azad, M. A. K. (2004). Effect of Potassium on Salinity Tolerance of Mungbean (Vigana radiata L. Wilczek). Journal of Biological Sciences, 4, 103-110. https://doi.org/10.3923/jbs.2004.103.110 
Kaisher, M. S., Rahman, M. A., Amin, M. H. A., Amanullah, A. S. M., \& Ahsanullah, A. S. M. (2010). Effects of sulphur and boron on the seed yield and protein content of mungbean. Bangladesh Research Publication Journal, 3, 1181-1186.

Kurdali, F., Farid, Al-Ain, \& Shamma, M. A. (2002). Nodulation, dry matter production and $\mathrm{N}_{2}$ fixation by fababean and chickpea as affected by soil moisture potassium fertilizer. Journal of Plant Nutrition, 25(2), 355-368. https://doi.org/10.1081/PLN-100108841

Kurhade, P. P., Sethi, H. N., \& Zadode, R. S. (2015). Effect of different levels of potassium on yield, quality, available nutrient and uptake of blackgram. International Journal of Agricultural Sciences, 11(1), 175-178. https://doi.org/10.15740/HAS/IJAS/11.1/175-178

Lindsay, W. L., \& Norvell, W. A. (1978). Development of DTPA soil test for zinc, iron, manganese and copper. Soil Science Society of American Journal, 42, 421-428. https://doi.org/10.2136/sssaj1978.03615995004200030009x

Mengel, K., \& Kirkby, E. A. (1987). Principles of plant nutrition. $4^{\text {th }}$ Edition. Int. Potash Inst. Worblaufen-Bern, Switzerland.

Mirza, H., Borhannuddin, B., M. H. M., Kamrun Nahar, Md. Shahadat Hossain, Jubayer Al Mahmud, Md. Shahadat Hossen, Abdul, A. C. M. M., \& Masayuki, F. (2018). Potassium: a vital regulator of plant responses and tolerance to abiotic stresses. Agronomy. https://doi.org/10.3390/agronomy8030031

Musinguzi, P., Tenywa, J. S., \& Bekunda, M. A. (2010). Strategic Nutrient Management of Field pea In Southwestern Uganda. African Journal of Food Agriculture Nutrition and Development (AJFAND online), 10(6), Published by ASSCAT, Kenya. https://doi.org/10.4314/ajfand.v10i6.58066

Narendra, K., Kumar, R., \& Sharma, O. P. (2009). Nutrient uptake and yield of mungbean vigna radiata (1.)wilczek as influenced by organic manures, psb and phosphorus fertilization. Environment \& Ecology, 27 (4B), 2002-2005.

Nelson, D. W., \& Sommers, L. E. (1982).Total carbon, organic carbon and organic matter. In A. L. Page, R. H. Miller, \& D. R. Keeney (Eds.), Methods of Soil Analysis (Part 2, 2nd ed., pp. 539-580). American Society of Agronomy, Madison, USA.

Ogbodo, E. N. (2011). Effect of crop residue on soil chemical properties and rice yield on an Ultisol at Abakaliki, Southeastern Nigeria. World Journal of Agricultural Sciences, 7, 13-18.

Olsen, S., \& Sommer, L. E. (1982). Phosphorus. In A. L. Page, R. H. Miller, \& D. R. Keeney (Eds.), Methods of Soil Analysis (Part 2, 2nd ed., pp. 403-427). American Society of Agronomy, Madison, USA.

Page, A. L., Miller, R. H., \& Keeney, D. R. (Eds.). (1982). Agronomy Series 9 ASA, SSSA. Methods of Soil Analysis (Part 2, 2nd ed., pp. 403-427). American Society of Agronomy, Madison, USA.

Paul, F., Brentrup, F., BruuIsema, T., Garcia, F., Norton, R., \& Zingore, S. (2014). 
Nutrient/fertilizer use efficiency: measurement, current situation and trends. IFA, IWMI, IPNI and IPI.

Persson, Jan-Ake, Wennerholm, M., \& O’Halloram, S. (2008). Handbook for Kjeldahl Digestion. Published by FOSS, DK-3400 Hilleroed, Denmark. ISBN 91-630-3471-9.

Piper, C. S. (1966). Soil and Plant Analysis. Adelaide University Press, Australia.

Pranav, K., Pravesh, K., Tarkeshwar, S., Anil, K. S., \& Ram, I. Y. (2014). Effect of different potassium levels on mungbean under custard apple based agri-horti system. African Journal of Agricultural Research, 9(8), 728-734. https://doi.org/10.5897/AJAR2013.7883

Quddus, M. A., Naser, H. M., Hossain, M. A., \& Abul, H. M. (2014). Effect of zinc and boron on yield and yield contributing characters of lentil in low Ganges river floodplain soil at madaripur, bangladesh. Bangladesh Journal of Agricultural Research, 39(4), 591-603. https://doi.org/10.3329/bjar.v39i4.22538

Sadaf, A., \& Tahir, M. (2017). Effect of Potassium on Growth, Yield and Quality of Mungbean under Different Irrigation Regimes. Bulletin of Biological and Allied Sciences Research, 2(4), 1-10.

Saket, K., Dan, S. J., \& Rajesh, S. (2018). Growth and Yield Response of Mung Bean (Vigna radiata L.) in Different Levels of Potassium. Acta Scientific Agriculture, 2(6), 23-25.

Salam, M. A., Solaiman, A. R. M., Karim, A. J. M. S., \& Saleque, M. (2014). System productivity, nutrient use efficiency and apparent nutrient balance in rice-based cropping systems. Archives of Agronomy and Soil Science, 60(6), 747-764. https://doi.org/10.1080/03650340.2013.849805

Singh, R. K., Athokpam, K., Singh, H. S., Nandini, L. N., \& Chongtham. (2002). Effect on nitrogen, phosphorus and potassium on the growth, yield and nutrient uptake of blackgram (Vigna mungo, L). Journal of Agricultural Science Society of North-East India. 15(2), 175-177.

Srinivasarao, Ch., Masood, A., Ganeshamurthy, A. N., \& Singh, K. K. (2003). Potassium requirements of pulse crops. Better Crops International, 17(1).

Statistix 10. Analytical Software. (1985). Po Box 12185, Tallahassee, FL 32317, Copy right (C) 1985-2013.

Sultana, S., Ullah, J., Karin, F., \& Asaduzzaman. (2009). Response of mungbean to intregated nitrogen and weed managements. American-Eurasian Journal of Agronomy, 2(2), 104-108.

Tariq, M., Khaliq, A., \& Umar, M. (2001). Effect of phosphorus and potassium application on growth and yield response of mungbean (Vigna radiata L.). Journal of Biological Sciences, 1(6), 427-428. https://doi.org/10.3923/jbs.2001.427.428

Thalooth, A. T., Tawfik, M. M., \& Mohamed, H. M. (2006). A comparative study on the effect of foliar application of zinc, potassium and magnesium on growth, yield and some chemical constituents of green gram plants grown under water stress conditions. World 
Journal of Agricultural Sciences, 2, 37-46.

Thesiya, M. N., Chovatia, P. K., \& Kikani, V. L. (2013). Effect of potassium and sulphur on growth and yield of black gram [Vigna mungo (L.) hepper] under rainfed condition. Legume Research, 36(3), 255-258.

Yang, X. E., Wang, W. M., \& He, Z. (2004). Physiological and genetic characteristics of high nutrient efficiency of plants in acid soils, 78-83.

\section{Copyright Disclaimer}

Copyright for this article is retained by the author(s), with first publication rights granted to the journal.

This is an open-access article distributed under the terms and conditions of the Creative Commons Attribution license (http://creativecommons.org/licenses/by/4.0/). 